\title{
Root Biomass Distribution with Root and Shoot Development at Different Growth Stages of Wild, Ancient and Modern Wheat Species
}

\author{
Hayati Akman* \\ Seed Department, Sarayönü Vocational School, Selçuk University, 42430 Konya, Turkey
}

\begin{tabular}{l}
\hline A R T I C L E I N F O \\
Research Article \\
Received 23 June 2017 \\
Accepted 25 September 2017 \\
\hline
\end{tabular}

Keywords:

Wild

Ancient wheat species

Modern wheat species,

Root traits

Shoot traits

*Corresponding Author:

E-mail: hayatiakman@selcuk.edu.tr

\begin{abstract}
A B S T R A C T
This study was conducted to investigate root and shoot traits of wild, ancient and modern wheat genotypes belonging to 8 different species at long tubes under field weather conditions. It was found significant differences between genotypes with regard to root and shoot traits. The research results indicated that root biomass distribution of genotypes at GS 31 ad GS 69, respectively was found $59.2 \%$ and $56.3 \%$ in $0-30 \mathrm{~cm}, 76.7 \%$ and $71.9 \%$ in $0-60 \mathrm{~cm}$. Modern wheats (Çeşit 1252, Konya 2002) and Triticum vavilovii (ancient wheat) had high root biomass distribution in top soil. In the study, species with AABBDD genomes had higher root length than those with AABB, AABBGG and AA genomes. Triticum dicoccoides, Triticum timopheevii and Triticum monococcum had lower values than other genotypes in terms of root length, crown root number, root biomass, shoot biomass and plant height at both growth stages (GS 31 and GS 69), while Triticum vavilovii and Triticum spelta (hexaploid) took part in the front. Accordingly, Triticum vavilovii and Triticum spelta may be used in breeding programs to improve new modern cultivars with high root and shoot traits.
\end{abstract}

DOI: https://doi.org/10.24925/turjaf.v5i11.1422-1428.1390

\section{Introduction}

Wheat (Triticum L. spp.) has been one of the most significant staple crops since it was originally domesticated about 10.000 years ago. It is currently grown from temperate, irrigated to dry areas, high precipitation to warm area, humid to dry and cold environments, with an annual production in the world over 729 million tons in 2014 (Faostat, 2017).

The oldest hulled and widespread wheat species are defined as spelt wheat (Triticum spelta), einkorn (Triticum monococcum) and emmer (Triticum dicoccon) (Suchowilska et al., 2009). Triticum boeoticum has been considered to be the progenitor of cultivated diploid einkorn wheat, Triticum monococcum L. (Özkan et al., 2010). Triticum vavilovii is another hulled wheat comprised by Triticum aestivum (Dvorak et al. 1998). Those hulled wheat species have transition between wild and cultivated wheat species and may harbor the genetic variation significant for new modern cultivars (Adu et al., 2011). Wild emmer used in the study, Triticum dicoccoides is called wild type of progenitor of durum and bread wheats (McFadden \& Seares 1946, Peleg et al., 2005) as well as Triticum dicoccon Schrank Syn. Triticum dicoccum Schub. L.. Another wild tetraploid species,
Triticum araraticum Jakubz. $\left(\mathrm{GGA}^{\mathrm{u}} \mathrm{A}^{\mathrm{u}}\right)$ is progenitor of domesticated Triticum timopheevii (Özkan et al., 2010). Triticum dicoccoides and Triticum araraticum was derived the diploid wheat Triticum urartu (Dvorak et al., 1993).

Ancient wheat species and wild wheat relatives have been reported to have tolerant genes against biotic and abiotic stress factors (Gill et al., 2006). Therefore, ancient and wild wheat species can be utilized in breeding programs to improve superior genotypes with large and deep rooting as well as high yield. It was reported that the root system size was correlated with grain yield (Heřmanská et al., 2015). However, studies on root system of those genotypes are insufficient because root studies have difficulty to conduct and harvest. Deeper roots are able to plants to take up from deeper soil profile when particularly water is available at deep soil profile, while extensive root growth and distribution may help to access water and nutrients under drought conditions (Prasad et al., 2008).

This study aimed to investigate root and shoot traits in different modern, ancient and wild wheat species in field environment conditions. 


\section{Materials and Methods}

\section{Experimental Site, Soil and Weather Conditions}

This research was conducted in Central Anatolian conditions, Konya province, Turkey during 2014-2015 growing seasons. The research field is located at $38^{\circ} 15^{\prime} 58^{\prime \prime} \mathrm{N} 32^{\circ} 24^{\prime} 23^{\prime \prime} \mathrm{E}$ at altitude of 1061 above mean sea level. The soilless media as soil consisted of the mixture of peat $(70 \%)$ and perlite $(30 \%)$. The soil at the experimental area has a loam texture and is slightly acidic, high in organic matter, and calcareous. It is adequate for $\mathrm{K}_{2} \mathrm{O}, \mathrm{Zn}$, and $\mathrm{Cu}$ and high for $\mathrm{Mg}$. In addition, $\mathrm{P}_{2} \mathrm{O}_{5}$ and $\mathrm{Mn}$ is found in the soil as very high.

The climate of the Konya can be defined as semiarid continental. In the region, monthly averages of meteorological data during the 2014-2015 experimental seasons and long term are given in Figure 1. According to the meteorological data in the region, there was $322.6 \mathrm{~mm}$ in the long term (1960-2014) and $582.2 \mathrm{~mm}(2014-2015)$ for rainfall, $11.7^{\circ} \mathrm{C}$ for the long-term temperature and $13.2^{\circ} \mathrm{C}$ for average annual temperature. In the research period (2014/11-2015/5) during about 7 months, rainfall was higher long term (245.1), with $321.4 \mathrm{~mm}$. Temperatures from November 2014 to May 2015 were higher than the long-term mean, especially in December, January, February and March, which were 6.0, 1.7, 3.5 and $7.4^{\circ} \mathrm{C}$, respectively, while the respective long-term averages were $1.8,0.0,1.5$ and $5.9^{\circ} \mathrm{C}$ (Figure 1).

\section{Field Experiment and Plant Materials}

The experiment was designed according to randomized complete block design with three replications. Field soil was dug about $2 \mathrm{~m}$ by a backhoe. We used cylindrical PVC tubes about $200 \mathrm{~cm}$ in long and $12 \mathrm{~cm}$ in diameter during per growth stage (Figure 2). The tubes were replaced to soil in 2-meter depth. Seeds were sown on November 12, 2014. A plant seedling in each tube was grown. We used two local modern durum and bread wheat cultivars such as Çeşit 1252 (adapted to dry land), Konya 2002 (adapted to irrigated land) and six wild and domesticated wheats with different genome (Table 1). Çeşit 1252 for durum wheat (tetraploid wheat) and Konya 2002 for bread wheat (hexaploid wheat) that are modern wheats cultivated large areas in Middle Anatolia were used for comparing with the wild and ancient wheat species. Those wild and ancient wheats were supplied from USDA-ARS Germplasm Resources Information Network.

Plots were thoroughly watered before sowing in order to provide fully emergence. In spring, plants were watered with sprinkler irrigation system at stem elongation (GS 31). At sowing, the fertilizer, DAP (18\% N, 46\% P2O5) $130 \mathrm{~kg} \mathrm{ha}^{-1}$, was applied as top-dressed to all tubes. A fertilizer solution including $17.0 \mathrm{~g}$ urea $(46 \% \mathrm{~N}), 3.5 \mathrm{ml}$ humic acid for tubes was applied, followed through sprinkler irrigation system.

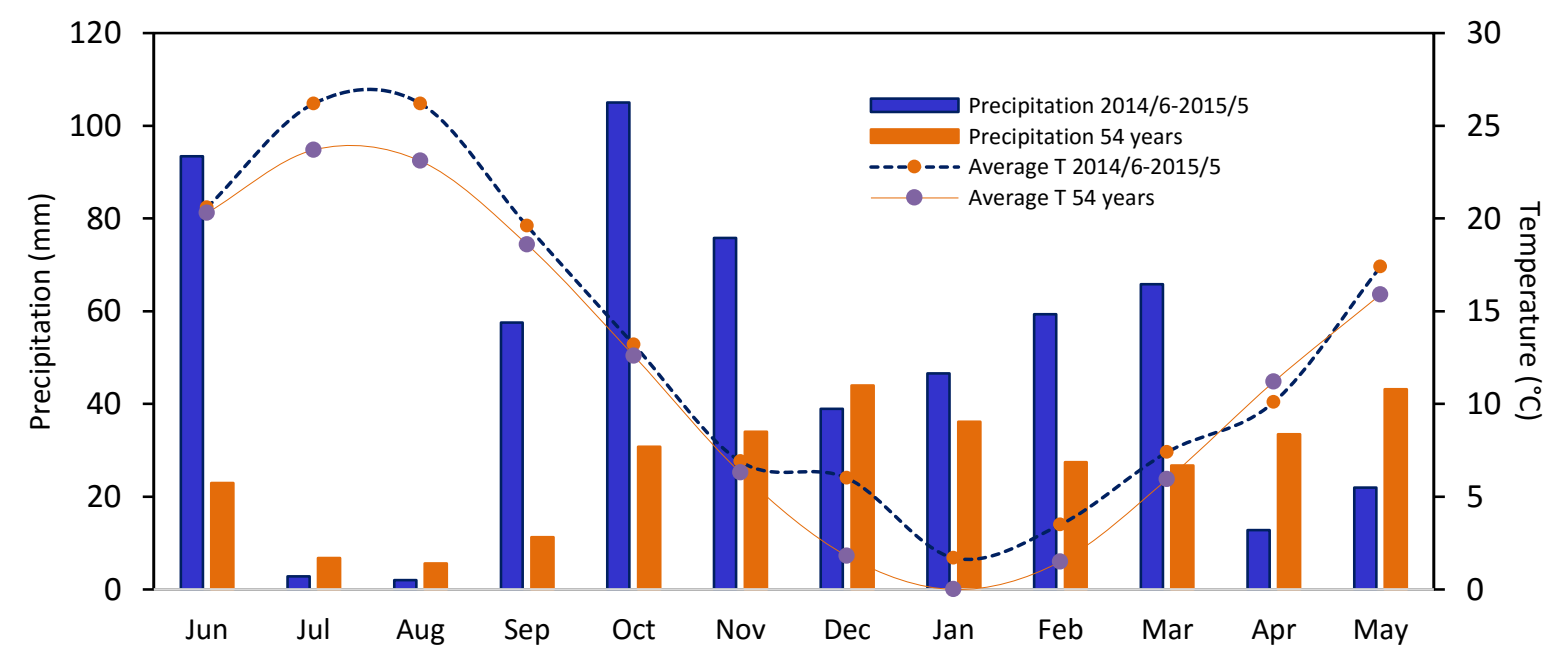

Figure 1 Precipitation (bars) and temperature (lines) in 2014-2015 (blue bars and lines) and the long term (54 years) mean (read bars and lines) in Konya Meteorology Station, Turkey.

Table 1 Traits of wheat cultivars and relatives used in the study

\begin{tabular}{|c|c|c|c|}
\hline Genotypes & Common Name & Genome & Chromosome number \\
\hline Triticum turgidum L. subsp. dicoccon (Schrank) Thell. & Domesticated emmer wheat & $\mathrm{A}^{\mathrm{u}} \mathrm{A}^{\mathrm{u}} \mathrm{BB}$ & $2 \mathrm{n}=4 \mathrm{x}=28$; tetraploid \\
\hline Triticum aestivum L. subsp. spelta (L.) Thell. & Spelt wheat & $\mathrm{A}^{\mathrm{u}} \mathrm{A}^{\mathrm{u}} \mathrm{BBDD}$ & $2 n=6 x=42$; hexaploid \\
\hline Triticum vavilovii Jakubz & Vavilov wheat & $\mathrm{A}^{\mathrm{u}} \mathrm{A}^{\mathrm{u}} \mathrm{BBDD}$ & $2 n=6 x=42 ;$ hexaploid \\
\hline Triticum timopheevii Zhuk. subsp. timopheevii & Timopheev's wheat & $\mathrm{A}^{\mathrm{u}} \mathrm{A}^{\mathrm{u}} \mathrm{GG}$ & $2 n=4 x=28$;tetraploid \\
\hline Triticum turgidum L. subsp. dicoccoides Thell. & Wild emmer & $\mathrm{A}^{\mathrm{u}} \mathrm{A}^{\mathrm{u}} \mathrm{BB}$ & $2 n=4 x=28$;tetraploid \\
\hline Triticum monococum subsp. monococcum & Domesticated einkorn & $\mathrm{A}^{\mathrm{u}} \mathrm{A}^{\mathrm{u}}$ & $2 \mathrm{n}=2 \mathrm{x}=14$; diploid \\
\hline Triticum aestivum L. subsp. aestivum (Konya 2002) & Bread wheat & $\mathrm{A}^{\mathrm{u}} \mathrm{A}^{\mathrm{u}} \mathrm{BBDD}$ & $2 n=6 x=42 ;$ hexaploid \\
\hline Triticum turgidum L. subsp. durum (Desf.) (Çeşit 1252) & Durum wheat & $\mathrm{A}^{\mathrm{u}} \mathrm{A}^{\mathrm{u}} \mathrm{BB}$ & $2 n=4 x=28$; tetraploid \\
\hline
\end{tabular}




\section{Measurement and Harvesting}

Measurement and counting of roots were made at stages of GS 31 (beginning of stem elongation; May 2, 2015) and GS 69 (complete of anthesis; post flowering; May 31, 2015) (Zadoks et al., 1974). Root media with nylon cover was taken out from PVC tubes and then nylon cover was cut (Figure 3). Roots were washed with pressurized water and then root length was measured as maximum root length of the longest root on a flat. Collected roots were divided to $0-30 \mathrm{~cm}, 30-60 \mathrm{~cm}, 60-90$ $\mathrm{cm}, 90-120 \mathrm{~cm}$ and remaining part of root above $120 \mathrm{~cm}$. Percentage of root biomass distribution per root length was determined by dry biomass weight. Roots and shoots were dried in a forced oven at $80^{\circ} \mathrm{C}$ for 48 hours to record root and shoot biomass.

\section{Statistical Analysis}

The data were analyzed according to the randomized complete block model of ANOVA. Differences between means were assessed with the Least Significant Difference (LSD) test at $\mathrm{P}=0.01$ or 0.05 levels of significance. Statistical analyses were performed using the MSTAT-C statistical software package (Mstatc, 1991). Normality test was used to determine if data set is well-modeled by a normal distribution at MINITAB statistical program (Minitab, 2010). Transformation was performed to percentage data of root biomass distribution in only $0-120 \mathrm{~cm}$ of root length due to a non-normal distribution data according to normality test $(\mathrm{P}<0.005)$.

\section{Results and Discussion}

Root length, root biomass, root/shoot ratio, root/total biomass ratio and crown root number

Root length of genotypes in stem elongation stage (GS 31) ranged from $113.3 \mathrm{~cm}$ (Triticum dicoccon) to 190.3 cm (Triticum spelta) (Table 2). Konya 2002, Triticum vavilovii and Triticum spelta had higher root length than other genotypes. Root length has been observed to reach up to $2 \mathrm{~m}$ in soil (Hoad et al., 2001). Palta et al. (2011) reported that vigorous root system with root biomass in early growth stage ensures to take up more water, which maintains faster leaf and shoot development. According to study, wheat species with ABD genome (hexaploid) possessed higher root length in beginning of stem elongation than other wheat species.

Barraclough et al. (1991) reported that plants with longer height had greater root length. Here, their finding is not always consistent with the research result. Triticum vavilovii and Triticum spelta with taller plant height had longer root length at GS 31, while Konya 2002 with shorter plant height included the same group in terms of root length with Triticum vavilovii and Triticum spelta.

Root biomass at GS 31 varied between 0.82 (Triticum dicoccoides) to $4.29 \mathrm{~g}$ (Triticum dicoccon), while root biomass at GS 69 was 1.47 (Triticum timopheevii) to 6.40 g (Triticum spelta) (Figure 5). Root biomass generally increased in genotypes except for Triticum dicoccon. Drop in root biomass between GS 31 and GS 69 may have occurred since loss in root biomass was more than increase in it. In both growth stage, ancient wheats, Triticum vavilovii and Triticum spelta had very high root biomass, however Triticum dicoccoides, Triticum timopheevii and Triticum monococcum possessed lower root biomass than other genotypes. Barraclough and Leigh (1984) showed that root length and weight of winter wheat increased fast up to flowering stage. According to the results acquired through this study, increase rate in root biomass between GS 31 and GS 69 was great in Triticum vavilovii (53.1\%), Triticum spelta (62.9\%), Triticum dicoccoides (103.7\%), modern wheats, Triticum durum (Çeşit 1252, 125.3\%) and Triticum aestivum (Konya 2002, 100.0\%), however root biomass decreased slightly in domesticated emmer wheat, Triticum dicoccon (-8.6\%). These modern wheats in GS 69 emerged the same group in the forefront with Triticum vavilovii and Triticum spelta with respect to root biomass.

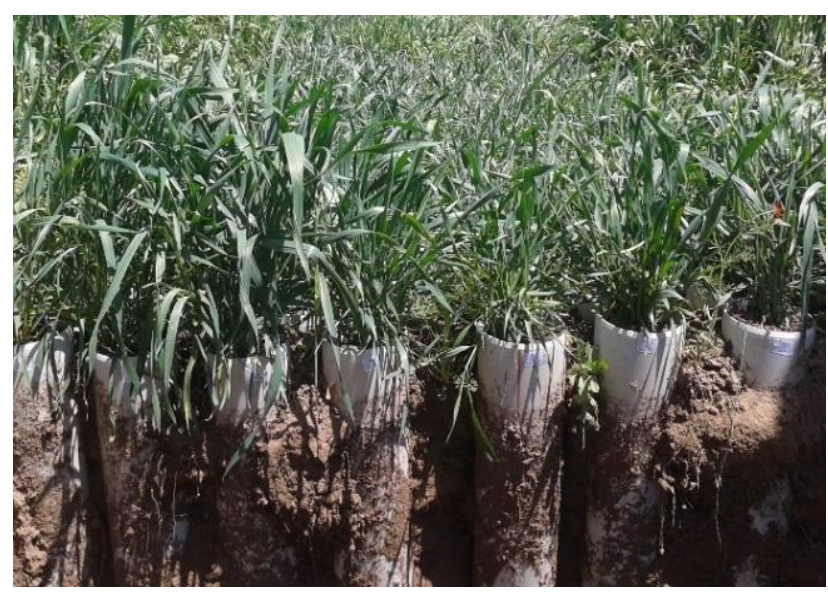

Figure 2 PVC tubes were replaced to $200 \mathrm{~cm}$ depth in soil under field environmental conditions. Plants are at stem elongation stage in 2015 May.

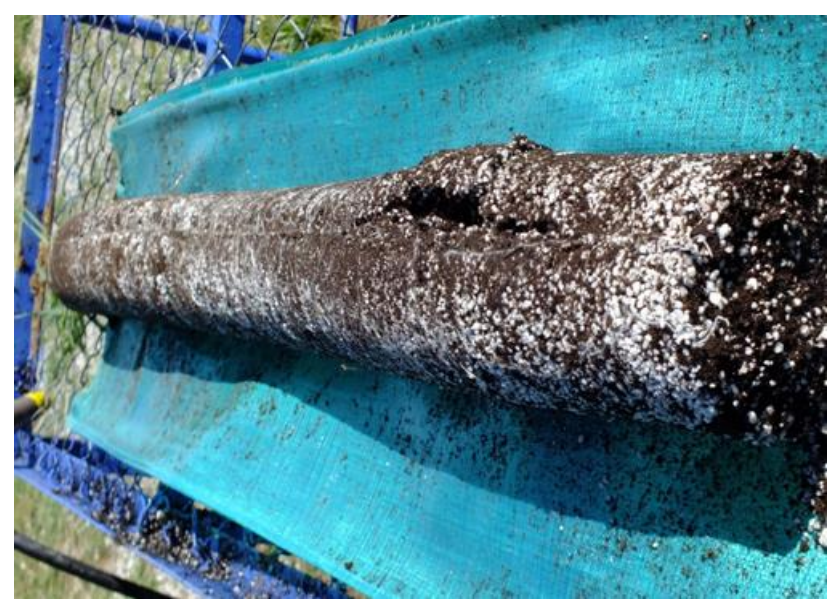

Figure 3 Roots were washed on sieve after nylon bag were removed from root media

Root/shoot ratio for species ranged from 0.25 (Triticum monococcum) to 0.80 (Çeşit 1252) in GS 31 and 0.11 (Triticum timopheevii) to 0.33 (Konya 2002) in GS 69 (Figure 5). These finding clearly demonstrated that root/shoot ratio was highly great in GS 31 compared to GS 69. Song et al., (2009) showed there is important and negative relation between grain yield and root: shoot ratio, which basically specified by root rather than shoot. Fang et al. (2011) indicated that the modern cultivar with lower root: shoot ratio had a higher grain yield than an old landrace cultivar. The current study showed that in both growth stages, modern wheats, Konya 2002, Çeşit 1252 
and as well as, Triticum spelta and Triticum dicoccon had higher value than other with respect to root/shoot and root/total biomass ratio.

Root/total biomass ratio varied 20.1 (Triticum monococcum) to $44.4 \%$ (Çeşit 1252) at GS 31 and 10.7 (Triticum timopheevii) to $32.9 \%$ (Konya 2002) at GS 69 (Figure 5). These results indicated in the both growth stages, Triticum vavilovii, Triticum timopheevii and Triticum dicoccoides had lower value than other genotypes.

Crown root number per plant widely varied in different wheat species, ranging from 29.3 to 83.3 at GS 31 and 62.0 to 122.0 in GS 69 (Figure 5). Saengwilai et al. (2011) reported that the crown root is significant for capturing resources in soil during vegetative growth after the first few weeks and still important during reproductive development. They further demonstrated that genotypes with low crown root number had $45 \%$ greater rooting depth in low-N soils than genotypes with high crown root. A previous study reported to vary crown root number and root size under Zn deficient conditions (Mori et al., 2016). Gao and Lynch (2016) indicated that low crown root number in maize improves drought tolerance by increasing rooting depth and water acquisition from the subsoil. In current study, Triticum dicoccoides and Triticum timopheevii had low crown root number, however in both growth stages, Triticum spelta, Triticum dicoccon and Konya 2002 had high crown root number.

\section{Root Biomass Distribution (RBD)}

The results of variance analysis for the root biomass distribution (RBD) are given in Table 3. The differences between wheat genotypes at $0-30 \mathrm{~cm}$ and $0-60 \mathrm{~cm}$ in root lengths in both growth stages were regarded considerable as $\mathrm{P}<0.01$, while RBD in $0-90 \mathrm{~cm}$ and $0-120 \mathrm{~cm}$ of root lengths at GS 69 and GS 31 were important as $\mathrm{P}<0.05$ and $\mathrm{P}<0.01$, respectively. In the study, average RBD in root length of genotypes at GS 31 was found $59.2 \%$ in $0-30$ $\mathrm{cm}, 76.7 \%$ in $0-60 \mathrm{~cm}, 90.0 \%$ in $0-90 \mathrm{~cm}$ and $97.5 \%$ in $0-$ $120 \mathrm{~cm}$, however at GS 69, it was $56.3 \%$ in $0-30 \mathrm{~cm}$, $71.9 \%$ in $0-60 \mathrm{~cm}, 83.7 \%$ in $0-90 \mathrm{~cm}$ and $96.0 \%$ in $0-120$ $\mathrm{cm}$. The results showed RBD in top soil was greater at GS 31 than GS 69. RBD in top soil can change due to that root length gave rise to at GS 69 or root biomass in top soil increased more than biomass in depth. At GS 31, Triticum dicoccon had greater RBD (Figure 4). At GS 69, cultivars, Konya 2002, Çeşit 1252 and Triticum vavilovii had higher RBD, but Triticum monococcum and Triticum spelta had lower RBD. Similarly, Miralles et al. (1997) and Ford et al. (2006) reported significant differences in root biomass among cultivars in $0-30 \mathrm{~cm}$. In top layer the genotype with greater root biomass is particularly more sensitive to drought (Ma et al., 2008) and may be advantage for capturing more water in adequately watered condition. Several researchers reported to be $65 \%$ of root biomass of wheat and barley in 0-30 cm top soil layer (Gregory et al. 1978), significant amount of root biomass at 0-60 cm (Hurd and Spartt, 1975, Lotfollahi, 2010), $50 \%$ in $0-20 \mathrm{~cm}$ (Morita et al., 1993), $75 \%$ in $0-60 \mathrm{~cm}$ at GS 92 under well watering condition (Zhang and $\mathrm{Hu}$, 2013), 70\% in 0-30 cm (Gale and Grigal, 1987).

According to the study, $76.7 \%$ and $71.9 \%$ of average root biomass at GS 31 and GS 69, respectively were found $0-60 \mathrm{~cm}$. Zhang et al. (2004) reported that $10 \%$ of root in below 1 meter of soil, however, the results revealed $10 \%$ at GS 31 and $16.3 \%$ at GS 69 of average root biomass was found below $90 \mathrm{~cm}$ of root length.

Plant Height, Shoot Biomass, Tiller Number and Crown Root Number Per Tiller

Plant height varied between 30.3 (Triticum dicoccoides) and $55.0 \mathrm{~cm}$ (Triticum spelta) in GS 31, however, $73.0 \mathrm{~cm}$ (Triticum dicoccon) and $124.0 \mathrm{~cm}$ (Triticum spelta) in GS 69 (Figure 5). At the both growth stages, Triticum spelta had the tallest plant height. Plant height of wheat species generally grew as twice as between GS 31 and GS 69, while that of Triticum dicoccoides increased highly from 30.3 to $96.3 \mathrm{~cm}$ about three-fold.

Shoot biomass of wheat species ranged from 2.1 (Triticum dicoccoides) to $8.2 \mathrm{~g}$ (Triticum vavilovii) at GS 31 (Figure 5). At GS 69, minimum and maximum shoot biomass obtained from $13.3 \mathrm{~g}$ (Triticum dicoccoides) and $31.4 \mathrm{~g}$ (Triticum spelta), respectively (Figure 5). Previous studies reported that shoot and root growth were significantly correlated (Wang and Below, 1992; Bertholdsson and Brantestam, 2009; Miralles et al., 1997). At both growth stages, Triticum vavilovii and Triticum spelta had high shoot biomass, while Triticum dicoccoides, Triticum timophevi and Triticum monococcum had low shoot biomass.

Table 2 Root length, tiller number and crown root number at GS 31 plant growth stage of ancient, wild and modern wheats

\begin{tabular}{|c|c|c|c|}
\hline Genotypes & Root length $(\mathrm{cm})$ & Tiller number /plant & Crown roots /tiller \\
\hline T.vavilovii & $180.3^{\mathrm{a}^{* *}}$ & $27.3^{\mathrm{c}^{* *}}$ & $1.44 b^{* *}$ \\
\hline T. spelta & $190.3^{\mathrm{a}}$ & $75.0^{\mathrm{a}}$ & $1.13^{\mathrm{bc}}$ \\
\hline T. dicoccon & $113.3^{\mathrm{c}}$ & $33.0^{\mathrm{bc}}$ & $2.25^{\mathrm{a}}$ \\
\hline T. dicoccoides & $132.7 b^{c}$ & $47.0^{\mathrm{b}}$ & $1.21^{\mathrm{bc}}$ \\
\hline T. timopheevii & $143.7^{\mathrm{b}}$ & $20.3^{c}$ & $0.72^{c}$ \\
\hline T. monococcum & $133.3^{\mathrm{bc}}$ & $34.3^{\mathrm{bc}}$ & $2.43^{\mathrm{a}}$ \\
\hline Çeşit 1252 & $122.2^{\mathrm{bc}}$ & $44.3^{\mathrm{b}}$ & $1.43^{\mathrm{b}}$ \\
\hline Konya 2002 & $172.3^{\mathrm{a}}$ & $25.7^{\mathrm{c}}$ & $1.51^{\mathrm{b}}$ \\
\hline Mean & 148.5 & 38.4 & 1.52 \\
\hline LSD & 24.5 & 15.7 & 0.57 \\
\hline $\mathrm{CV}(\%)$ & 15.7 & 16.8 & 15.5 \\
\hline
\end{tabular}


Table 3 Root biomass distribution (0-30, 0-60, 0-90, 0-120 cm lengths), root length, tiller number and crown roots/tiller in different growth stages of ancient, wild and modern wheats.

\begin{tabular}{|c|c|c|c|c|c|c|c|c|}
\hline \multirow{2}{*}{ Genotypes } & \multicolumn{2}{|c|}{$0-30 \mathrm{~cm}$} & \multicolumn{2}{|c|}{$0-60 \mathrm{~cm}$} & \multicolumn{2}{|c|}{$0-90 \mathrm{~cm}$} & \multicolumn{2}{|c|}{$0-120 \mathrm{~cm}$} \\
\hline & GS 31 & GS 69 & GS 31 & GS 69 & GS 31 & GS 69 & GS 31 & GS 69 \\
\hline T.vavilovii & $60.8^{\mathrm{b}^{* *}}$ & $67.3^{\mathrm{abc} * *}$ & $73.2^{\mathrm{bc} * *}$ & $77.6^{\mathrm{a}^{* * *}}$ & $84.3^{\mathrm{cd} * *}$ & $85.6^{\mathrm{ab}^{*}}$ & $97.4^{\mathrm{bc} * *}$ & $94.3^{\mathrm{bc} *}$ \\
\hline T. spelta & $59.3^{b}$ & $47.8^{\mathrm{d}}$ & $75.2^{\mathrm{bc}}$ & $62.1^{\mathrm{b}}$ & $86.3^{\text {bcd }}$ & $75.5^{\mathrm{c}}$ & $93.0^{\mathrm{c}}$ & $91.3^{c}$ \\
\hline T. dicoccon & $71.8^{\mathrm{a}}$ & $54.3^{\text {bcd }}$ & $87.8^{\mathrm{a}}$ & $68.6^{\mathrm{ab}}$ & $97.3^{\mathrm{a}}$ & $83.9^{\mathrm{ab}}$ & $100.0^{\mathrm{a}}$ & $97.9^{\mathrm{ab}}$ \\
\hline T. dicoccoides & $60.9^{b}$ & $46.4^{\mathrm{d}}$ & $76.1^{\mathrm{bc}}$ & $73.6^{\mathrm{ab}}$ & $98.4^{\mathrm{a}}$ & $81.1^{\mathrm{bc}}$ & $100.0^{\mathrm{a}}$ & $98.3^{\mathrm{a}}$ \\
\hline T. timopheevii & $57.0^{\mathrm{b}}$ & $49.8^{\mathrm{cd}}$ & $84.4^{\mathrm{ab}}$ & $66.4^{\mathrm{ab}}$ & $96.1^{\mathrm{a}}$ & $81.7^{\mathrm{bc}}$ & $99.0^{\mathrm{ab}}$ & $96.0^{\mathrm{ab}}$ \\
\hline T. monococcum & $45.8^{c}$ & $43.6^{\mathrm{d}}$ & $70.7^{\mathrm{c}}$ & $67.8^{\mathrm{ab}}$ & $90.6^{\mathrm{abc}}$ & $85.7^{\mathrm{ab}}$ & $99.1^{\mathrm{ab}}$ & $98.2^{\mathrm{ab}}$ \\
\hline Çeşit 1252 & $59.7^{b}$ & $71.9^{a}$ & $76.5^{\mathrm{abc}}$ & $79.2^{\mathrm{a}}$ & $94.1^{\mathrm{ab}}$ & $88.7^{\mathrm{a}}$ & $99.2^{\mathrm{ab}}$ & $96.6^{\mathrm{ab}}$ \\
\hline Konya 2002 & $58.3^{b}$ & $69.1^{\mathrm{ab}}$ & $69.4^{c}$ & $80.3^{\mathrm{a}}$ & $79.9^{d}$ & $87.3^{\mathrm{ab}}$ & $92.0^{c}$ & $95.3^{\mathrm{abc}}$ \\
\hline Mean & 59.2 & 56.3 & 76.7 & 71.9 & 90.0 & 83.7 & 97.5 & 96.0 \\
\hline LSD & 10.5 & 17.5 & 11.7 & 15.4 & 8.5 & 6.5 & 8.0 & 4.0 \\
\hline $\mathrm{CV}(\%)$ & 7.29 & 12.78 & 6.25 & 8.82 & 3.84 & 4.42 & 3.95 & 2.38 \\
\hline
\end{tabular}

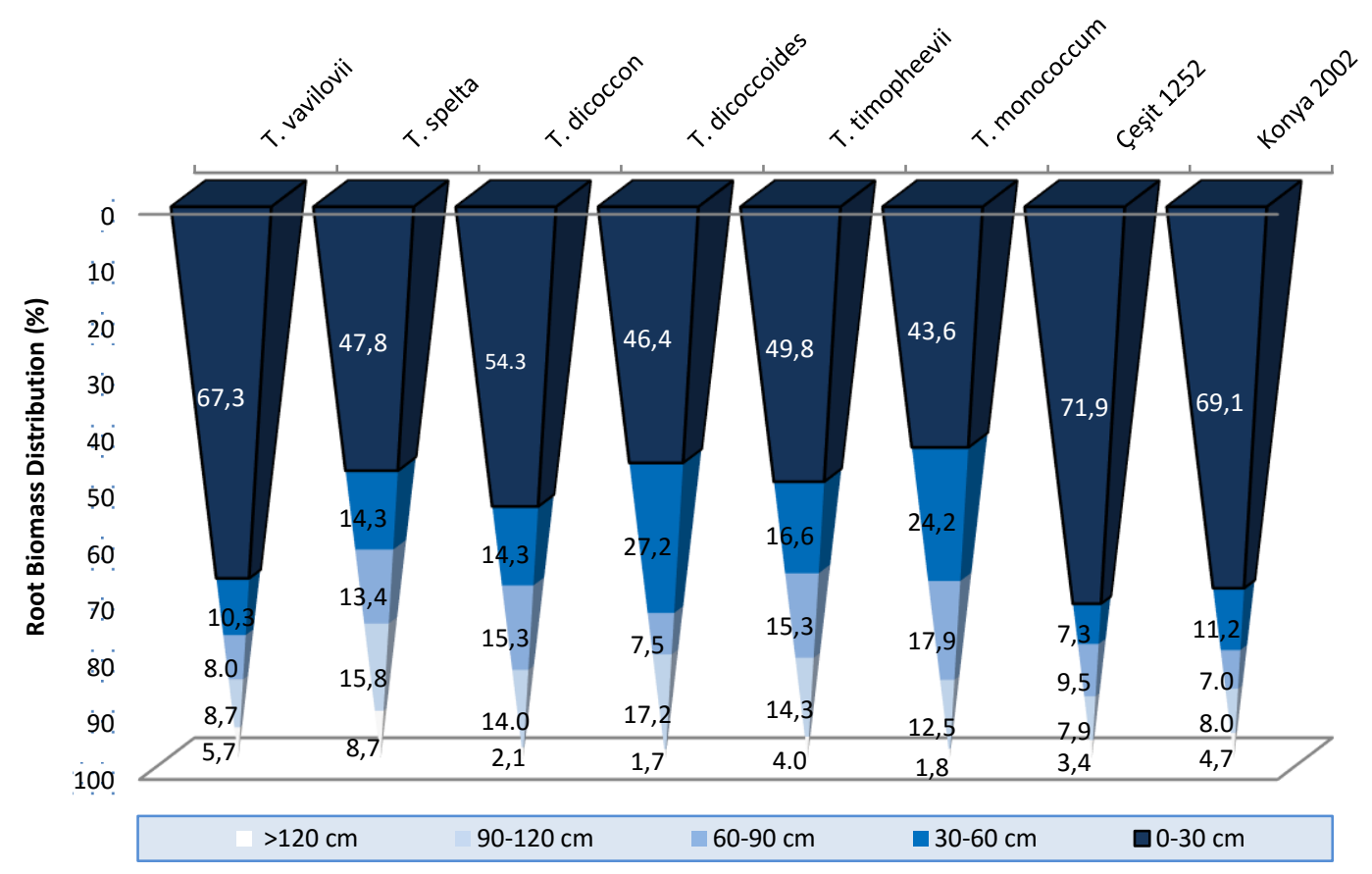

Figure 4 Root biobiomass distribution in 0-30 cm, 30-60 cm, $60-90 \mathrm{~cm}, 90-120 \mathrm{~cm}$ and $>120 \mathrm{~cm}$ root length

At GS 31, tiller number per plant changed between 20.3 (Triticum timopheevii) and 75.0 (Triticum spelta). Triticum monococcum (2.43) had high crown root number per tiller and Triticum timophevii (0.72) had minimum crown root number (Table 2). Manske and Vlek (2002) indicated that there was a positive relation between root number and tiller number. Tiller number in bread wheat reached maximum level after emerging about 60-70 days and then continued to decrease in tiller number up to flowering (K1lınç, 1989). The study results showed that Triticum timopheevii, Triticum vavilovii and Konya 2002 had lower tiller number per plant than other genotypes.

\section{Conclusions}

This work aimed to investigate root biomass distribution with root and shoot traits at different growth stages, including 8 different wheat species. Research results indicated that a large amount of root biomass was collected in the $0-60 \mathrm{~cm}$ root depth with $76.7 \%$ at GS 31 and $71.9 \%$ at GS 69. Average root proportion in total biomass was $59.2 \%$ at GS 31 and $56.3 \%$ at GS 69. Shoot biomass had higher than root growth between GS 31 and GS 69. Root length of genotypes at long tube reached about $190.0 \mathrm{~cm}$. In addition, it was found that Triticum vavilovii and Triticum spelta had generally high value in terms of root length, crown root number, root biomass, shoot biomass and plant height at GS 31 and GS 69, conversely Triticum dicoccoides, Triticum timopheevii and Triticum monococcum indicated low value. Those ancient wheat species are also considered to tolerant bioatic and abioitic stress conditions. In conclusion, Triticum vavilovii and Triticum spelta with high root and shoot traits may be evaluated for new modern cultivar improvement with superior root and shoot traits as well as tolerant to stress factors in breeding programs. 

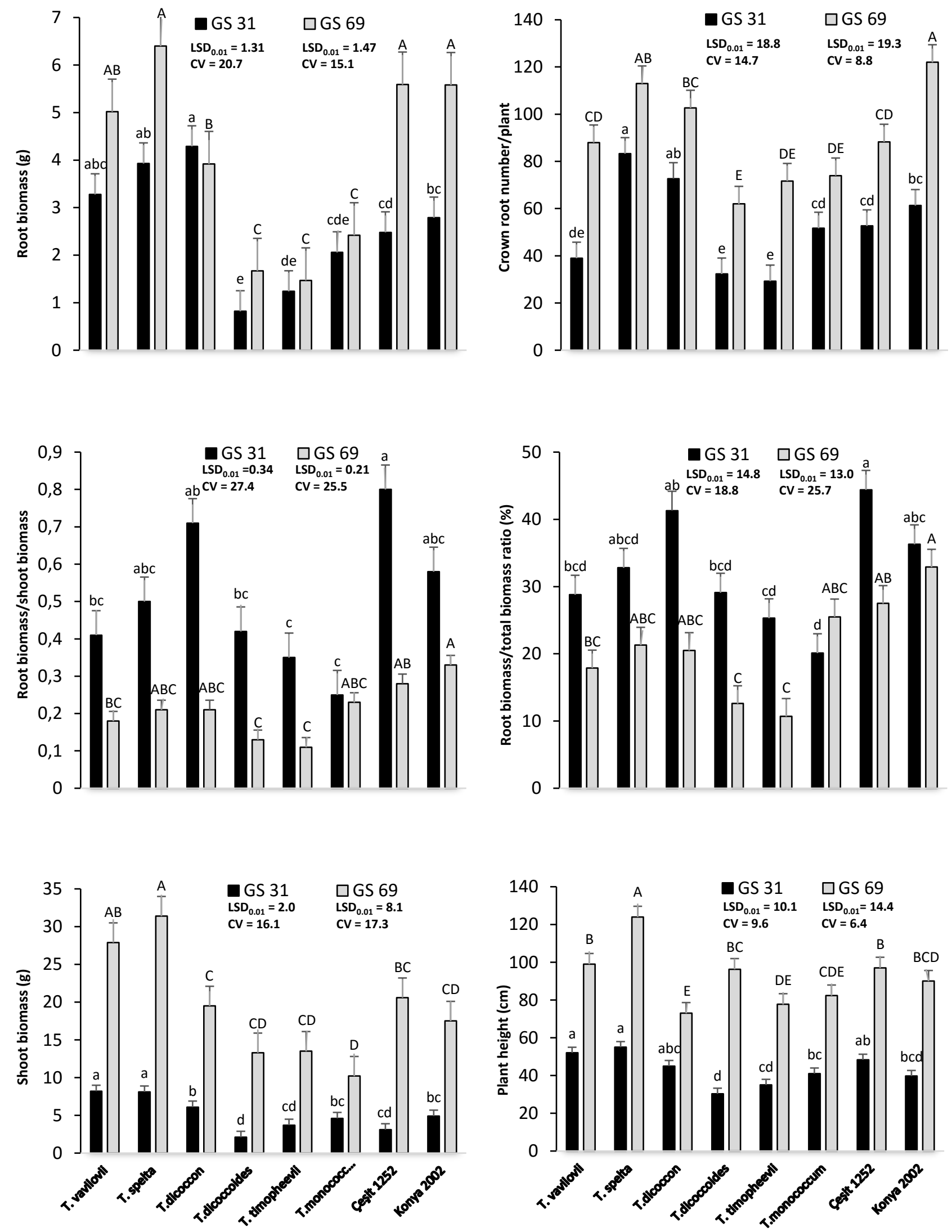

Figure 5 Root biomass, crown root number, root/shoot ratio, root/total biomass ratio, shoot bioabiomass and plant height in different growth stages of wild, ancient and modern wheat species. Bars with the same letter (s) are not significantly different at $\mathrm{P}<0.01$ according to the least significant difference (LSD) test. CV is the coefficient of variance. 


\section{Acknowledgement}

I would like to thank USDA-ARS Germplasm Resources Information Network to provide ancient and wild wheat genotypes.

\section{References}

Adu MO, Sparkes DL, Parmar A, Yawson DO. 2011. 'Stay green' in wheat: comparative study of modern bread wheat and ancient wheat cultivars. ARPN J Ag\&Bio Sci 6:16-24.

Barraclough, PB, Leigh RA. 1984. The growth and activity of winter wheat roots in the field: the effect of sowing date and soil type on root growth of high-yielding crops. The Journal of Agr. Sci.103: 59-74.

Barraclough PB, Weir AH, Kuhlmann H. 1991. Factors affecting the growth and distribution of winter wheat roots under UK field conditions. Developments in Agricultural and ManagedForest Eco. 24: 410-441.

Bertholdsson NO, Brantestam AK. 2009. A century of Nordic barley breeding- effects on early vigour root and shoot growth, straw length, harvest index and grain weight. Europ. J. Agronomy 30: 266-274. DOI: 10.1016/j.eja.2008.12.003.

Dvorak J, Diterlizzi P, Zhang HB, Resta P. 1993. The evolution of polyploidy wheats: identification of the A genome donor species. Genome 36: 21-31. DOI: 10.1139/g93-004.

Dvorak J, Luo MC, Yang ZL. 1998. Genetic evidence on the origin of Triticum aestivum L. In: Damania AB, Valkoun J, Willcox G, Qualset CO, editors. The origins of agriculture and crop domestication. Proceedings of the Harlan Symposium. Aleppo, Syria: ICARDA. p. 235-251.

Fang Y, Liu L, Xu BC, Li FM. 2011. The relationship between competitive ability and yield stability in an old and a modern winter wheat cultivar. Plant Soil 347: 7-23. DOI: 10.1007/s11104-011-0780-4.

Faostat, 2017. Accessed at: www.fao.org/faostat in June of 2017.

Ford KE, Gregory PJ, Gooding MJ, Pepler S. 2006. Genotype and fungicide effects on late-season root growth of winter wheat. Plant and Soil 284:33-44. DOI: 10.1007/s11104-006-0028-x.

Gale M, Grigal D. 1987. Vertical root distributions of northern tree species in relation to successional status. Can J For Res 17: 829-834. DOI: 10.1139/x87-131.

Gao Y, Lynch JP. 2016. Reduced crown root number improves water acquisition under water deficit stress in maize (Zea mays L.). J Exp Bot Adv 1-13. DOI: 10.1093/jxb/erw243

Gill BS, Friebe B, Raupp WJ, Wilson DL, Cox TS, Brown-Guedira GL, Sears RG, Fritz AK. 2006. Wheat genetics resource center: the first 25 years. Adv in Agron 89: 73-136. DOI: 10.1016/S0065-2113(05)89002-9.

Gregory PJ, McGowan M, Biscoe PV, Hunter B. 1978. Water relations of winter wheat: 1 . growth of the root system. The $\mathrm{J}$ Agr Sci 91: 91-102. DOI: 10.1017/S0021859600056653.

Heřmanská A, Středa T, Chloupek O. 2015. Improved wheat grain yield by a new method of root selection. Agron for Sust Dev 35: 195-202. DOI: 10.1007/s13593-014-0227-4.

Hoad S, Russell G, Lucas ME, Bingham IJ. 2001. The management of wheat, barley and oat root systems. Adv in Agron 74: 699 703. DOI: 10.1016/S0065-2113(01)74034-5.

Hurd EA, Spartt ED. 1975. Root patterns in crops as related to water and nutrient uptake. In Physiological aspects of dry land farming. (Ed US Gupta) pp 167-235. (Oxford IBH: New Dehli, India).

Kılınç M. 1989. Üç ekmeklik buğday çeşidinde tohum miktarının kardeşlenme özellikleri ve verim oluşumuna etkisi üzerine bir araştırma. Yük.Lis.Tezi, Çukurova Ünv. Fen Bil. Enst., Sayfa 13-15.

Lotfollahi MA. 2010. Wheat root length density as affected by nitrogen treatment. World Congress of Soil Science, Soil Solutions for a Changing World, 1-6 August 2010, Brisbane, Australia.
Ma SC, Xu BC, Li FM, Liu WZ, Huang ZB. 2008. Effects of root pruning on competitive ability and water use efficiency in winter wheat. Field Crops Res 105: 56-63. DOI: 10.1016/j.fcr.2007.07.005.

Manske GGB, Vlek PLG. 2002. Root architecture - Wheat as o model plant. p. 249 - 260. In: Waisel, Y., Eshel, A., Kafkafi, U. (ed.): Plant roots: The hidden half. Marcel Dekker Inc., New York, $1120 \mathrm{p}$.

McFadden ES, Seares ER. 1946. The origin of Triticum spelta and its free-threshing hexaploid relatives. J Heredity 37: 81-89. DOI: 10.1093/oxfordjournals.jhered.a105590.

Minitab. 2010. Minitab 16 statistical software. Minitab Inc., State College, Pennsylvania, USA.

Miralles DDJ, Slafer GA, Lynch V. 1997. Rooting patterns in nearisogenic lines of spring wheat for dwarfism. Plant and Soil 197: 79-86. DOI: 10.1023/A:1004207407979.

Mori A, Kirk GJD, Lee JS, Morete MJ, Nanda AK, JohnsonBeebout SE. 2016. Rice genotype differences in tolerance of zinc-deficient soils: evidence for the importance of root-induced changes in the rhizosphere. Front Plant Sci 6:1160. DOI: 10.3389/fpls.2015.01160.

Morita S, Okuda H, Abe J. 1993. Spatial distribution and structure of wheat root system. In: Low-input sustainable crop production systems in Asia. Korean Soc Crop Sci. p. 399-404.

Mstatc. 1991. Michigan State University. Wast Lansing, Michigan, USA.

Özkan H, Tuna M, Kilian B, Mori N, Ohta S. 2010. Genome size variation in diploid and tetraploid wild wheats. AoB Plants, 111. DOI: $10.1093 /$ aobpla/plq015.

Palta JA, Chen X, Milroy SP, Rebetzke GJ, Dreccer MF, Watt M. 2011. Large root systems: are they useful in adapting wheat to dry environments?. Funct Plant Biol 38: 347-354. DOI: 10.1071/FP11031.

Prasad PVV, Staggenborg SA, Ristic Z. 2008. Impacts of Drought and/or Heat Stress on Physiological, Developmental, Growth, and Yield Processes of Crop Plants. Capter 11. Ahuja, LR, Reddy VR, Saseendran SA, Yu Qiang (ed.), Response of Crops to Limited Water Understanding and Modeling Water Stress Effects on Plant Growth Processes.

Saengwilai P, Tian X, Lynch JP. 2011. Low crown root number enhances nitrogen acquisition from low-nitrogen soils in maize. Plant Phy 166: 581-589. DOI: 10.1104/pp.113.232603.

Song L, Li FM, Fan XW, Xiong YC, Wang WQ, Wu XB. 2009. Soil water availability and plant competition affect the yield of spring wheat. Eur. J. Agron. 31: 51-60. 10.1016/j.eja.2009.03.003

Suchowilska E, Kandler W, Sulyok M, Wiwart M, Krska R. 2009. Mycotoxins profiles in the grain of Triticum monococcum, Triticum diccocum and Triticum spelta after head infection with Fusarium culmorum. J Sci Food Agric 90: 556-565. DOI: 10.1002/jsfa.3844.

Wang X, Below FE. 1992. Root growth, nitrogen uptake, and tillering of wheat induced by mixed-nitrogen source. Crop Sci 32: 997-1002. 10.2135/cropsci1992.0011183X003200040033.

Peleg Z, Fahima T, Abbo S, Krugman T, Nevo E, Yakir D, Saranga Y. 2005. Genetic diversity for drought resistance in wild emmer wheat and its ecogeographical associations. Plant, Cell \& Env 28: 176-191. DOI: 10.1111/j.1365-3040.2005.01259.x.

Zadoks JC, Chang TT, Konzak CF. 1974. A decimal code for the growth stages of cereals. Weed Res., 14: 415-421.

Zhang X, Pei D, Chen SY. 2004. Root growth and soil water utilization of winter wheat in the North China Plain. Hydrol Processes 18: 2275-2287. DOI: 10.1002/hyp.5533.

Zhang X, Hu C. 2013. Root growth and distribution in relation to different water levels. Capter 3 at enhancing understanding and quantification of soil-root growth interactions. Dennis Timlin and Laj R. Ahuja (ed.), Advances in Agricultural Systems Modeling, Volume 4. 